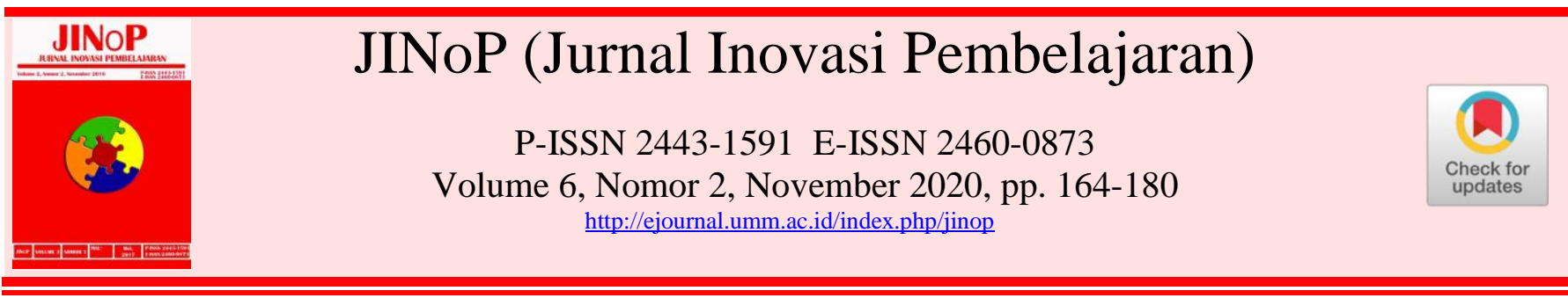

\title{
Meningkatkan keaktifan siswa dalam mata pelajaran bahasa Indonesia dengan menggunakan pendekatan saintifik dalam kegiatan lesson study
}

\author{
Arif Setiawan $^{1)^{*}}$, Gigit Mujianto ${ }^{2)}$, Fauzan $^{3)}$ \\ ${ }^{1}$ Program Studi Pendidikan Bahasa Indonesia, Fakultas Keguruan dan Ilmu Pendidikan, Universitas \\ Muhammadiyah Malang, Jl. Raya Tlogomas 246, Malang, Indonesia \\ ${ }^{2}$ Program Studi Pendidikan Bahasa Indonesia, Fakultas Keguruan dan Ilmu Pendidikan, Universitas \\ Muhammadiyah Malang, Jl. Raya Tlogomas 246, Malang, Indonesia \\ ${ }^{3}$ Program Studi Pendidikan Bahasa Indonesia, Fakultas Keguruan dan Ilmu Pendidikan, Universitas \\ Muhammadiyah Malang, Jl. Raya Tlogomas 246, Malang, Indonesia
}

arifsetiawan1988@gmail.com*; gigit_m@yahoo.com; fauzan@umm.ac.id

*Penulis Koresponden

\section{ABSTRAK}

Mata pelajaran bahasa Indonesia merupakan salah satu mata pelajaran yang sering diremehkan oleh para siswa. Akan tetapi, kenyataannya pada evaluasi akhir banyak ditemukan nilai terendah yang diperoleh siswa berasal dari mata pelajaran bahasa Indonesia. Penelitian ini bertujuan untuk meningkatkan keaktifan siswa pada mata pelajaran bahasa Indonesia. Subjek penelitian adalah 27 siswa kelas VII SMP Muhammadiyah 06 Dau Malang. Program lesson study ini dilakukan dalam 4 siklus dengan menerapkan pendekatan saintifik yang diimplementasikan melalui strategi pembelajaran inkuiri. Strategi tersebut berimplikasi pada pemakaian metode inkuiri, diskusi, dan kunjung kelompok. Hasil penelitian menunjukkan keatifan siswa dapat ditingkatkan. Peningkatan keaktifan siswa tersebut beriringan dengan tujuan pembelajaran dengan menggunakan pendekatan saintifk yang meliputi (1) menanya/menjawab teks prosedur, (2) menerapkan penulisan teks prosedur, dan (3) mengomunikasikan menanggapi teks prosedur. Berdasarkan hal tersebut dapat disimpulkan pemakaian pendekatan saintifik dalam kegiatan lesson study dapat meningkatkan keaktifan siswa dalam mata pelajaran bahasa Indonesia.

Kata kunci: Keaktifan Siswa; Lesson Study; Pendekatan Saintifik.

\section{ABSTRACT}

Bahasa Indonesia subject is one of the subjects that is often underestimated by students. However, it was found that the lowest scores obtained by students came from Indonesian subjects in the final evaluation. This research aimed to increase student activeness in Indonesian subjects by analysing 27 research subjects on grade VII students of SMP Muhammadiyah 06 Dau Malang. This lesson study program was carried out in 4 cycles by applying a scientific approach through an inquiry learning strategy. This strategy implied to the use of inquiry, discussion, and group visits methods. The results showed that students activity could be improved. Increasing the activeness of students goes parallel with the learning objectives by using a scientific approach which includes (1) asking / answering procedure texts, (2) applying procedural text writing, and (3) communicating responding to procedural texts. Based on the result, it can be concluded that the use of a scientific approach in lesson study activities can increase student activeness in Bahasa Indonesia subjects.

Keywords: Student Activity; Lesson Study; Scientific Approach.

diunggah: 2018-12-05, direvisi: 2020-11-12, diterima: 2020-11-20, dipublikasi: 2020-11-20

Copyright (c) 2020 Setiawan et al

This is an open access article under the CC-BY license

Cara sitasi: Setiawan, A., Mujianto, G., \& Asihono, D. (2020). Meningkatkan keaktifan siswa kelas vii dalam mata pelajaran bahasa Indonesia dengan menggunakan pendekatan saintifik dalam kegiatan lesson study. JINoP (Jurnal Inovasi Pembelajaran), 6(2). 164-180. https://doi.org/10.22219/jinop.v6i2.7177 


\section{PENDAHULUAN}

Proses pembelajaran yang dilakukan di sekolah memiliki tujuan yang akan dicapai (Nurhayati, 2020). Salah satu tujuan yang akan dicapai dalam proses pembelajaran adalah perubahan tingkah laku (Nurhayati, 2020), yang meliputi aspek kognitif, afektif, serta psikomotorik (Hardini, 2015; Mardiyan, 2012; Ramlah, Firmansyah, \& Zubair, 2015). Selain perubahan tingkat laku, proses pembelajaran juga memerlukan partisipasi aktif siswa, komunikasi dua arah siswa dengan guru, dan keaktifan siswa dalam mengikuti pembelajaran (Megawati \& Sari, 2012; Ramlah et al., 2015; Wibowo, 2016; Widhiyasari, Umami, \& Suja, 2019). Keaktifan siswa akan mewujudkan pembelajaran sesuai dengan skenario yang telah dirancang oleh guru (Sundari, 2013; Yulianto, Fatchan, \& Astina, 2017). Selain itu, keaktifan siswa dalam proses pembelajaran akan sangat berpengaruh terhadap proses perkembangan berpikir, emosi, dan sosial budaya yang sangat kompleks (Wibowo, 2016).

Upaya nyata untuk mewujudkan proses pembelajaran yang sesuai dengan skenario dapat direalisasikan dengan menggunakan pendekatan, strategi, dan media (Rusminati \& Sulistyawati, 2018), yang telah ditentukan oleh guru dalam perencanaan pembelajaran (Bintari, Sudiana, \& Putrayasa, 2014). Pendekatan saintifik menjadi salah satu pendekatan yang dapat dipilih dan digunakan dalam penyelenggaraan proses pembelajaran, karena pendekatan saintifik mengedepankan beberapa tahapan yang meliputi (a) mengamati, (b) merumuskan masalah, (c) merumuskan hipotesis, (d) menganalisis data, (e) menarik kesimpulan, dan (f) mengomunikasikan konsep (Machin, 2014). Beberapa tahapan yang begitu kompleks tersebut, pendekatan saintifik bertujuan untuk mengantarkan siswa benar-benar merasakan bahwa belajar itu merupakan sebuah kebutuhan (Machin, 2014; Sukmasari, Putra, \& Kristiantari, 2015). Dengan tahapan yang begitu kompleks, panjang, dan berorientasi pada bagaimana memberikan pengalaman nyata dalam pembelajaran pada siswa (Sukmasari et al., 2015; Wijayanti, 2014), maka pendekatan saintifik dapat digunakan pada semua mata pelajaran, salah satunya adalah mata pelajaran bahasa Indonesia.

Mata pelajaran bahasa Indonesia merupakan salah satu mata pelajaran yang sering diremehkan oleh siswa (Kristina, 2018; Wardiati, 2017). Siswa menganggap bahwa mata pelajaran bahasa Indonesia adalah mata pelajaran yang mudah karena telah digunakan dalam kehidupan sehari-hari (Kristanto, Hapsari, Nita, \& Maimunah, 2015; Wardiati, 2017). Akan tetapi, pada kenyataannya nilai terendah yang sering didapatkan oleh siswa setelah evaluasi yakni berasal dari mata pelajaran bahasa Indonesia (Kristanto et al., 2015). Selain itu, nilai Ujian Nasional (UN) bahasa Indonesia dari tahun ke tahun pada tingkat SMP dan SMA selalu mendapatkan nilai di bawah rata-rata (Gidot, Mashudi, \& Matsum, 2013). Nilai mata pelajaran bahasa Indonesia selalu di bawah nilai mata pelajaran yang lainnya, seperti matematika dan bahasa Inggris (Gidot et al., 2013; Wardiati, 2017). Kondisi tersebut hampir terjadi di seluruh sekolah-sekolah yang ada di Indonesia, salah satunya SMP Muhammadiyah 6 Dau Malang.

Melalui fenomena tersebut, dapat dikatakan bahwa berbagai macam pendekatan yang telah dicetuskan sangat dibutuhkan dalam suatu pembelajaran. Pendekatan-pendekatan tersebut tentunya diharapkan mampu meningkatkan minat belajar siswa terhadap bahasa Indonesia yang harus dibangun sejak memasuki bangku SMP (kelas VII) (Kristina, 2018). Di samping itu, pendekatan yang digunakan dalam suatu pembelajaran diharapkan mampu menghidupkan suasana 
belajar agar tidak monoton dan membosankan (Setiawan, 2020). Pendekatan pembelajaran dapat diartikan sebagai kumpulan metode dan cara yang digunakan oleh guru dalam melakukan pembelajaran (Setiawan \& Mufassaroh, 2020; Winarsih \& Sulistyowati, 2016). Salah satu pendekatan yang dapat digunakan dalam pembelajaran yaitu pendekatan saintifik (Wijayanti, 2014).

Pendekatan saintifik merupakan suatu pendekatan pembelajaran yang berbasis ilmiah (scientific) yang diyakini mampu membangkitkan minat belajar siswa (Machin, 2014; Rudyanto, 2016). Dalam pendekatan saintifik, siswa tidak hanya mendapatkan informasi dari guru semata (Rusminati \& Sulistyawati, 2018), melainkan dapat berasal dari mana saja, serta siswa menjadi pusat belajar, bukan lagi menjadi objek pembelajaran (Permatasari, 2014). Adapun langka-langkah dalam pendekatan saintifik meliputi (1) mengamati, (2) menanya, (3) mengumpulkan data, (4) mengolah informasi, dan (5) mengomunikasikan (Machin, 2014). Penerapan pendekatan saintifik dalam pembelajaran melibatkan keterampilan proses seperti mengamati, mengklasifikasi, mengukur, meramalkan, menjelaskan, dan menyimpulkan (Dewi, 2016; Machin, 2014). Dalam melaksanakan proses tersebut arahan dari guru sangat diperlukan, namun arahan tidak sepenuhnya diberikan, melainkan sesuai dengan tingkat kedewasaan siswa atau semakin tingginya tingkat kelas siswa (Bintari et al., 2014). Oleh sebab itu, karakter, skill, dan kognisi siswa sangat dibutuhkan dalam proses pembelajaran dengan menggunakan pendekatan saintifik.

Pembelajaran dengan menggunakan pendekatan saintifik menekankan pada partisipasi aktif siswa (Rudyanto, 2016) dalam pembelajaran. Partisipasi aktif siswa menjadi sebuah modal berharga dalam kesuksesan pembelajaran yang telah dituangkan guru dalam perencanaan (Mustofa, Susilo, \& Al Muhdhar, 2016), yang berorientasi pada kualitas dan inovasi pembelajaran (Rustono, 2008; A. Winarsih \& Mulyani, 2012). Kualitas dan inovasi pembelajaran merupakan hal yang mutlak ada dalam pembelajaran, salah satu cara untuk meningkatkan keduanya adalah dengan menyelenggarakan pembelajaran melalui kegiatan lesson study (Rahayu, Mulyani, \& Miswadi, 2012). Lesson study merupakan model pembinaan profesi pendidik memalui kegiatan yang bersifat kolaboratif dan berkelanjutan (Rustono, 2008). Dari sisi inovasi pembelajaran, lesson study juga dianggap sebagai sebuah penggerak gairah belajar di sekolah (Rustono, 2008), karena pada praktiknya melibatkan semua unsur di sekolah untuk menuju perbaikan yang lebih baik (Murtiani, Fauzan, \& Ratnawulan, 2012; Susanto, 2012; Wulandari, Arifin, \& Irmawati, 2015). Selain itu, lesson study juga memposisikan siswa sebagai sumber belajar (Agustiana, Putra, \& Farida, 2018), sehingga siswa dapat saling bertukar informasi (sharing) ataupun ide/gagasan dalam kegiatan pembelajaran yang bermuara pada terjadinya proses interaksi antarsiswa (Agustiana et al., 2018; Jurniati, 2009). Dengan demikian, pendekatan saintifik melalui kegiatan lesson study dapat digunakan sebagai salah satu cara untuk meningkatkan keaktifan siswa dalam mengikuti mata pelajaran bahasa Indonesia.

Adapun penelitian sejenis yang sudah dilakukan sebelumnya lebih banyak membahas mengenai penerapan lesson study dalam pembelajaran (Agustiana et al., 2018; Jurniati, 2009; Murtiani et al., 2012; Mustofa et al., 2016; Pantiwati, 2015; Rahayu et al., 2012; Rusminati \& Sulistyawati, 2018; Tristiantari \& Sumantri, 2016; A. Winarsih \& Mulyani, 2012; Wulandari et al., 2015). Penelitian lain yang memfokuskan penerapan lesson study untuk meningkatkan keaktifan siswa dalam pembelajaran (Susanto, 2012; Yulianto et al., 2017). Selain itu, terdapat penelitian 
lain yang menekankan pada pendekatan saintifik (Bintari et al., 2014; Permatasari, 2014; Rusminati \& Sulistyawati, 2018; Setiawan \& Mufassaroh, 2020; Sukmasari et al., 2015; Wijayanti, 2014; Winarsih \& Sulistyowati, 2016). Sepengetahuan penulis, belum pernah dilakukan penelitian mengenai penerapan lesson study dengan menggunakan pendekatan saintifik pada mata pelajaran bahasa Indonesia untuk meningkatkan keaktifan siswa. Penelitian ini akan memberikan informasi yang sangat signifikan dalam perencanaan dan pelaksanaan pembelajaran. Selain itu, penelitian ini juga dapat memberikan informasi mengenai tingkat partisipatif dan keaktifan siswa dalam mengikuti pembelajaran bahasa Indonesia. Adapun tujuan penelitian ini adalah untuk meningkatkan keaktifan siswa pada mata pelajaran bahasa Indonesia menggunakan pendekatan saintifik dalam kegiatan lesson study.

\section{METODE}

Penelitian ini merupakan Penelitian Tindakan Kelas (PTK) berbasis lesson study yang diterapkan di kelas VII SMP Muhammadiyah 6 Dau. Penelitian dilaksanakan pada bulan Juli-Agustus 2019, subjek penelitian ini adalah siswa kelas VII 1 SMP Muhammadiyah 6 Dau yang berjumlah 30 siswa. Kegiatan PTK berbasis Lesson study dilakukan dalam 2 siklus, yang terdiri dari tahapan plan (merencanakan), do (melaksanakan), dan see (merefleksi). Adapun bagan perencanaan pelaksanaan kegiatan lesson study sebagaimana Gambar 1 (Mustofa et al., 2016).

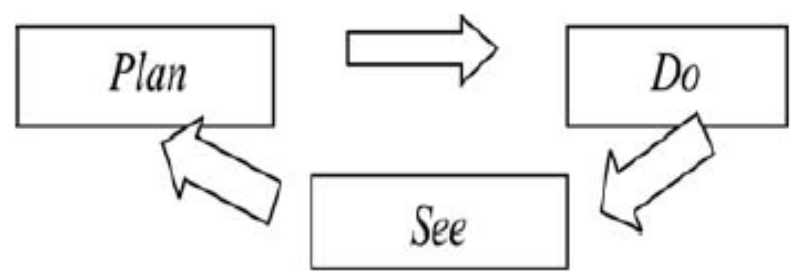

\section{Gambar 1 Bagan Pelaksanaan Lesson Study}

Tahapan pelaksanaan kegiatan lesson study sebagaimana Gambar 1 dimulai dari plan (perencanaan), dalam kegiatan ini guru, observer, dan peneliti berkolaborasi secara bersama untuk menyusun dan memperbaiki Rencana Pelaksanaan Pembelajaran (RPP) sebelum dan proses pembelajaran. RPP disusun berdasarkan pendekatan saintifik yang berorientasi pada proses keaktifan siswa dalam pembelajaran. Do (pelaksanaan), pada kegiatan ini terdapat dua poin penting dalam pelaksanaannya yang terdiri dari proses pembelajaran dan observasi. Kegiatan pembelajaran yang dimaksudkan yaitu kegiatan pembelajaran sesuai dengan proses perencanaan, sedangkan kegiatan observasi dilakukan oleh guru, observer, dan peneliti. Tahapan yang paling akhir adalah see (refleksi), pada tahapan ini guru, observer, dan peneliti melakukan pengkajian terhadap proses pembelajaran yang sudah dilaksanakan, serta memberikan saran dan masukan untuk perbaikan proses pembelajaran yang sudah dilakukan.

Instrumen penelitian yang digunakan dalam penelitian ini meliputi (a) lembar observasi $L S$, (b) Lembar Kerja Siswa (LKS), dan (c) rubrik penilaian keaktifan siswa. Teknik pengumpulan data dalam penelitian ini menggunakan teknik dokumentasi yang dilaksanakan selama proses pembelajaran. Analisis data yang digunakan dalam penelitian ini adalah deskriptif. Analisis deskriptif digunakan 
untuk memperoleh data mengenai keaktifan siswa dalam mata pelajaran bahasa Indonesia menggunakan pendekatan saintifik. Teknik analisis data setiap siklus dilakukan dengan cara perbandingan pencapaian siswa dengan rumus:

$$
\mathrm{N}=\frac{\sum \mathrm{NS}}{\mathrm{NS}} \mathrm{X} 100
$$

Keterangan:

$$
\begin{array}{ll}
\mathrm{N} & =\text { rata-rata nilai } \\
\sum \mathrm{NS} & =\text { jumlah nilai siswa } \\
\mathrm{NS} & =\text { nilai siswa }
\end{array}
$$

Hasil persentase rata-rata nilai yang didapatkan dari siswa kemudian diubah menjadi predikat keaktifan siswa yang diadaptasi dari model penelitian (Yulianto et al., 2017), sebagaimana Tabel 1 dan Tabel 2.

\begin{tabular}{|c|c|c|c|c|c|c|c|c|c|c|c|c|}
\hline \multirow{2}{*}{ No } & \multirow{2}{*}{ Nama Siswa } & \multicolumn{3}{|c|}{ Bertanya } & \multicolumn{3}{|c|}{ Menjawab } & \multicolumn{3}{|c|}{$\underset{\text { usi }}{\operatorname{Argumen} / \text { Sol }}$} & \multirow{2}{*}{$\begin{array}{l}\text { Total } \\
\text { Skor }\end{array}$} & \multirow{2}{*}{ Nilai } \\
\hline & & 1 & 2 & 3 & 1 & 3 & 5 & 5 & 7 & 8 & & \\
\hline 1 & & & & & & & & & & & & \\
\hline 2 & & & & & & & & & & & & \\
\hline 3 & & & & & & & & & & & & \\
\hline 4 & & & & & & & & & & & & \\
\hline 5 & & & & & & & & & & & & \\
\hline
\end{tabular}

Tabel 1. Kualifikasi Tingkat Keaktifan Siswa

\begin{tabular}{ccccc}
\hline No & $\begin{array}{c}\text { Persentase Keaktifan } \\
\text { Siswa }\end{array}$ & $\begin{array}{c}\text { Taraf } \\
\text { Keberhasilan }\end{array}$ & Nilai Angka & Nilai Huruf \\
\hline 1 & $85-100$ & Sangat Baik & A & 5 \\
2 & $70-84$ & Baik & B & 4 \\
3 & $55-69$ & Cukup & C & 3 \\
4 & $50-54$ & Kurang & D & 2 \\
5 & $0-49$ & Sangat Kurang & E & 1 \\
\hline
\end{tabular}

Tabel 2. Rubrik Keaktifan Siswa

Keterangan:

1) Bertanya $=$ Skor $1=1$ kali bertanya; Skor $2=2$ kali bertanya; Skor $3=3$ kali bertanya.

2) Menjawab $=$ Skor $1=$ menjawab salah; Skor $3=$ menjawab kurang benar; Skor $5=$ menjawab benar.

3) Argumen/solusi $=$ Skor $5=$ argumentasi/solusi belum dapat diterima kebenarannya; Skor $7=$ argumentasi/solusi kurang dapat diterima kebenarannya; Skor $8=\operatorname{argumentasi} /$ solusi dapat diterima kebenarannya.

4) $\quad$ Nilai $=\left(\sum\right.$ Skor Total/9) $X 100$

\section{HASIL DAN PEMBAHASAN}

Pelaksanaan kegiatan lesson study di SMPM 6 Dau telah berjalan sesaui dengan rencana awal yaitu sebanyak 2 siklus yang terdiri dari plan, do, dan see. Masing-masing kegiatan tersebut telah terinci dan dijelaskan sebagai berikut.

\section{Prasiklus}

Hasil observasi pada kegiatan pada prasiklus menunjukkan pembelajaran yang diselenggarakan oleh guru dan keaktifan siswa sebagaimana berikut. Pertama, guru masih belum meminta siswa untuk bertanya, menjawab, dan memberikan 
argumentasi, guru belum melakukan penilaian terhadap kelompok yang presentasi, dan guru masih belum memberikan tes di akhir pembelajaran untuk mengukur sejauh mana tingkat pemahaman materi. Kedua, siswa masih belum menunjukkan partisipasi aktif dalam pembelajaran sebagaimana yang tertera dalam Tabel 3. Berdasarkan hasil observasi, siswa masih belum ada yang bertanya, menjawab pertanyaan guru, dan memberikan argumentasi/solusi terhadap beberapa contoh yang dilontarkan oleh guru. Berdasarkan hasil observasi pada kegiatan prasiklus memberikan informasi umum bahwa pembelajaran masih belum menarik dan berjalan dua arah. Terlihat masih sangat dominan guru sebagai pusat pembelajaran, serta siswa masih asyik dengan dunia mereka, berbincang dengan teman se-bangku atau bermalas-malasan dalam mengikuti pembelajaran.

Tabel 3. Rubrik Keaktifan Siswa pada Kegiatan Prasiklus

\begin{tabular}{lllllllllllll}
\hline \multirow{2}{*}{ No } & \multirow{2}{*}{ Nama Siswa } & \multicolumn{2}{c}{ Bertanya } & \multicolumn{7}{c}{ Menjawab } & \multicolumn{3}{c}{ Argumen/Sol } & \multirow{2}{*}{ Total } & \multirow{2}{*}{ Nilai } \\
\cline { 3 - 9 } & & $\mathbf{1}$ & $\mathbf{2}$ & $\mathbf{3}$ & $\mathbf{1}$ & $\mathbf{3}$ & $\mathbf{5}$ & $\mathbf{5}$ & $\mathbf{7}$ & $\mathbf{8}$ & Skor & \\
\hline 1 & A & - & - & - & - & - & - & - & - & - & - & - \\
2 & B & - & - & - & - & - & - & - & - & - & - & - \\
3 & C & - & - & - & - & - & - & - & - & - & - & - \\
4 & D & - & - & - & - & - & - & - & - & - & - & - \\
5 & E & - & - & - & - & - & - & - & - & - & - & - \\
6 & F & - & - & - & - & - & - & - & - & - & - & - \\
7 & G & - & - & - & - & - & - & - & - & - & - & - \\
8 & H & - & - & - & - & - & - & - & - & - & - & - \\
9 & I & - & - & - & - & - & - & - & - & - & - & - \\
10 & J & - & - & - & - & - & - & - & - & - & - & - \\
11 & K & - & - & - & - & - & - & - & - & - & - & - \\
12 & L & - & - & - & - & - & - & - & - & - & - & - \\
13 & M & - & - & - & - & - & - & - & - & - & - & - \\
14 & N & - & - & - & - & - & - & - & - & - & - & - \\
15 & O & - & - & - & - & - & - & - & - & - & - & - \\
16 & P & - & - & - & - & - & - & - & - & - & - & - \\
17 & Q & - & - & - & - & - & - & - & - & - & - & - \\
18 & R & - & - & - & - & - & - & - & - & - & - & - \\
19 & S & - & - & - & - & - & - & - & - & - & - & - \\
20 & T & - & - & - & - & - & - & - & - & - & - & - \\
21 & U & - & - & - & - & - & - & - & - & - & - & - \\
22 & V & - & - & - & - & - & - & - & - & - & - & - \\
23 & W & - & - & - & - & - & - & - & - & - & - & - \\
24 & Q & - & - & - & - & - & - & - & - & - & - & - \\
25 & Y & - & - & - & - & - & - & - & - & - & - & - \\
26 & Z & - & - & - & - & - & - & - & - & - & - & - \\
27 & AA & - & - & - & - & - & - & - & - & - & - & - \\
28 & AB & - & - & - & - & - & - & - & - & - & - & - \\
29 & AC & - & - & - & - & - & - & - & - & - & - & - \\
30 & AD & - & - & - & - & - & - & - & - & - & - & - \\
\hline & & & & & & & & & & & & \\
\hline
\end{tabular}

Berdasarkan kondisi tersebut, maka perlu ditawarkan model pembelajaran yang lebih membuat suasana pembelajaran menjadi lebih aktif dan menyenangkan, salah satunya dengan kegiatan lesson study. Dengan demikian, disepakati pelaksanaan pembelajaran bahasa Indonesia di SMP Muhammadiyah 6 Dau melalui kegiatan lesson study. Adapun materi yang dipilih dalam kegiatan pembelajaran melalui kegiatan lesson study adalah teks prosedur. 


\section{Siklus I}

Plan 1 adalah kegiatan mendiskusikan pembelajaran yang akan dilaksanakan pada $D o$ 1. Materi yang akan disajikan pada $D o 1$ adalah teks prosedur dengan guru model Reni Octaviani Sari, S.Pd. Pada Plan 1 ini tim mendiskusikan indikator pembelajaran yang meliputi (a) mengidentifikasi ciri-ciri teks prosedural dan (b) menentukan jenis-jenis teks prosedural. Untuk mencapai indikator tersebut, guru model menggunakan pendekatan saintifik dengan strategi pembelajaran mandiri yang diimplementasikan melalui metode inkuiri, pemberian tugas, dan proyek. Hasil Plan 1 adalah pemaduan antara strategi pembelajaran mandiri dengan strategi pembelajaran interaktif melalui diskusi dan sharing dalam kelompok kecil untuk mengidentifikasi teks prosedural. Untuk mendukung rancangan tersebut, maka materi pelajaran disusun untuk memotivasi siswa agar aktif bertanya, menjawab, dan memberikan argumentasi/solusi. Tindak lanjut Plan 1 adalah menyusun RPP berbasis Pendekatan Saintifik yang bertujuan untuk membangun inisiatif individu, peningkatan diri, dan kemampuan berpikir kritis melalui diskusi dan sharing di antara siswa. Di samping itu, guru model bersama observer menyusun materi pokok yang dapat mendorong keaktifan dan kreativitas siswa, lembar observasi keaktifan siswa, dan tes untuk menguji pemahaman siswa. Kegiatan diskusi dalam plan sebagaimana pada Gambar 2.

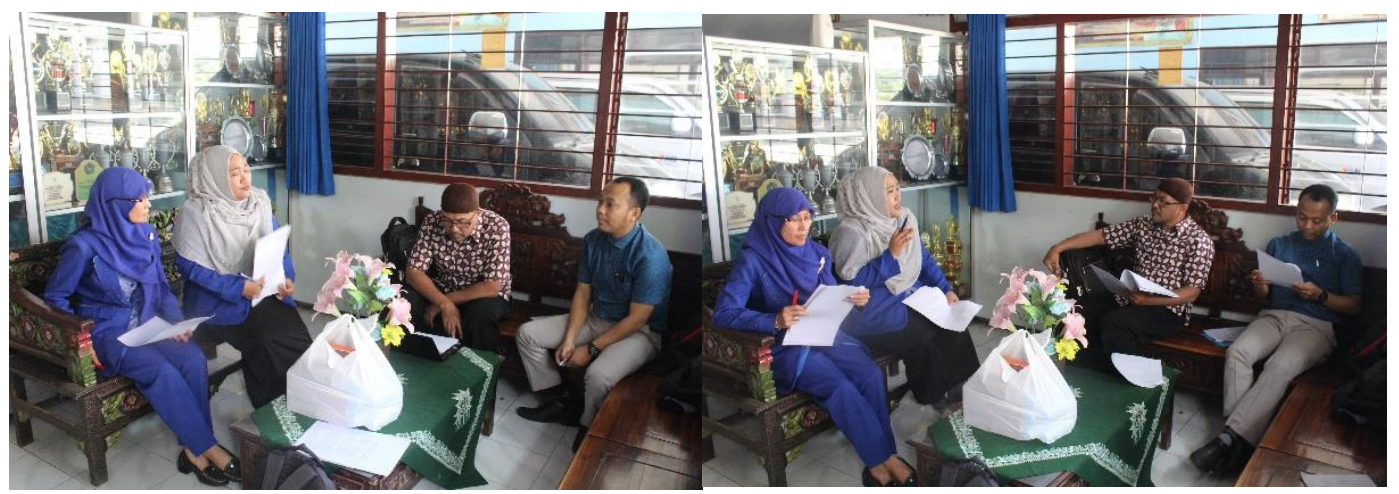

Gambar 2. Kegiatan Plan dengan Guru Model, Guru Observer, dan Peneliti

Do 1 adalah kegiatan melaksanakan pembelajaran. Dalam kegiatan ini siswa mengidentifikasi ciri-ciri teks prosedural. Setelah itu, siswa menentukan jenis-jenis teks prosedural. Do 1 menghadirkan beberapa aktivitas pembelajaran yang terkait dengan kegiatan menentukan ciri-ciri dan jenis-jenis teks prosedural. Aktivitas pembelajaran diawali dengan penyampaian materi pokok oleh guru model selama \pm 45 menit. Selama penyampaian materi pokok tersebut, guru model memberi contoh teks prosedural melalui vidio, sehingga menarik perhatian siswa dan memberikan stimuls pada sisiwa untuk bertanya. Stimulus yang telah diberikan oleh guru menjadi sebuah modal yang sangat bagus untuk memancing siswa lebih aktif. Pembelajaran yang dilaksanakan pada do 1 telah dirancang sebelumnya oleh guru model menggunakan pendekatan saintifik dengan strategi pembelajaran mandiri yang diimplementasikan melalui metode inkuiri, pemberian tugas, dan proyek. Model pembelajaran tersebut memberikan dampak yang cukup signifikan terhadap proses pembelajaran yang diselenggarakan, utamanya pada keaktifan siswa. Hal ini ditunjukkan dengan antusiasme yang cukup tinggi untuk mengikuti pembelajaran pada $d o$, kondisi ini dapat dilihat pada Tabel 4 dan Gambar 3. 
Tabel 4. Rubrik Keaktifan Siswa pada Kegiatan Siklus I

\begin{tabular}{|c|c|c|c|c|c|c|c|c|c|c|c|c|}
\hline \multirow[t]{2}{*}{ No } & \multirow{2}{*}{ Nama Siswa } & \multicolumn{3}{|c|}{ Bertanya } & \multicolumn{3}{|c|}{ Menjawab } & \multicolumn{3}{|c|}{$\underset{\text { usi }}{\text { Argumen/Sol }}$} & \multirow{2}{*}{$\begin{array}{l}\text { Total } \\
\text { Skor }\end{array}$} & \multirow[t]{2}{*}{ Nilai } \\
\hline & & 1 & 2 & 3 & 1 & 3 & 5 & 5 & 7 & 8 & & \\
\hline 1 & $\mathrm{~A}$ & - & - & - & - & - & - & - & - & - & - & - \\
\hline 2 & B & - & - & - & $\sqrt{ }$ & - & - & - & - & - & 1 & 11,11 \\
\hline 3 & $\mathrm{C}$ & - & - & - & - & - & - & - & - & - & - & - \\
\hline 4 & D & - & - & - & - & $\sqrt{ }$ & - & - & - & - & 3 & 33,33 \\
\hline 5 & E & - & - & - & - & - & - & - & - & - & - & - \\
\hline 6 & F & - & - & - & - & - & - & - & - & - & - & - \\
\hline 7 & $\mathrm{G}$ & - & $\sqrt{ }$ & - & - & - & - & - & - & - & 2 & 22,22 \\
\hline 8 & $\mathrm{H}$ & - & - & - & - & - & - & - & - & - & - & - \\
\hline 9 & I & - & - & - & - & $\sqrt{ }$ & - & - & - & - & 3 & 33,33 \\
\hline 10 & $\mathrm{~J}$ & - & - & - & - & - & - & - & - & - & - & - \\
\hline 11 & $\mathrm{~K}$ & - & - & - & $\sqrt{ }$ & - & - & - & - & - & 1 & 11,11 \\
\hline 12 & $\mathrm{~L}$ & - & - & - & - & - & - & - & - & - & - & - \\
\hline 13 & $\mathrm{M}$ & - & - & - & - & - & - & - & - & - & - & - \\
\hline 14 & $\mathrm{~N}$ & - & - & - & - & - & - & - & - & - & - & - \\
\hline 15 & $\mathrm{O}$ & - & - & $\sqrt{ }$ & - & - & - & - & - & - & 3 & 33,33 \\
\hline 16 & $\mathrm{P}$ & - & - & - & - & - & - & - & - & - & - & - \\
\hline 17 & $\mathrm{Q}$ & - & - & - & - & - & - & - & - & - & - & - \\
\hline 18 & $\mathrm{R}$ & - & - & - & - & $\sqrt{ }$ & - & - & - & - & 3 & 33,33 \\
\hline 19 & $\mathrm{~S}$ & - & - & - & - & - & - & - & - & - & - & - \\
\hline 20 & $\mathrm{~T}$ & $\sqrt{ }$ & - & - & - & - & - & - & - & - & 1 & 11,11 \\
\hline 21 & $\mathrm{U}$ & - & - & - & - & - & - & - & - & - & - & - \\
\hline 22 & V & - & - & - & - & - & - & - & - & - & - & - \\
\hline 23 & W & - & - & - & - & - & - & - & - & - & - & - \\
\hline 24 & Q & - & $\sqrt{ }$ & - & - & - & - & - & - & - & 2 & 22,22 \\
\hline 25 & $\mathrm{Y}$ & - & - & - & - & - & - & - & - & - & - & - \\
\hline 26 & Z & - & - & - & $\sqrt{ }$ & - & - & - & - & - & 1 & 11,11 \\
\hline 27 & AA & - & - & - & - & - & - & - & - & - & - & - \\
\hline 28 & $\mathrm{AB}$ & $\sqrt{ }$ & - & - & - & - & - & - & - & - & 1 & 11,11 \\
\hline 29 & $\mathrm{AC}$ & - & - & - & - & $\sqrt{ }$ & - & - & - & - & 3 & \\
\hline 30 & $\mathrm{AD}$ & - & - & - & - & - & - & - & - & - & - & - \\
\hline
\end{tabular}

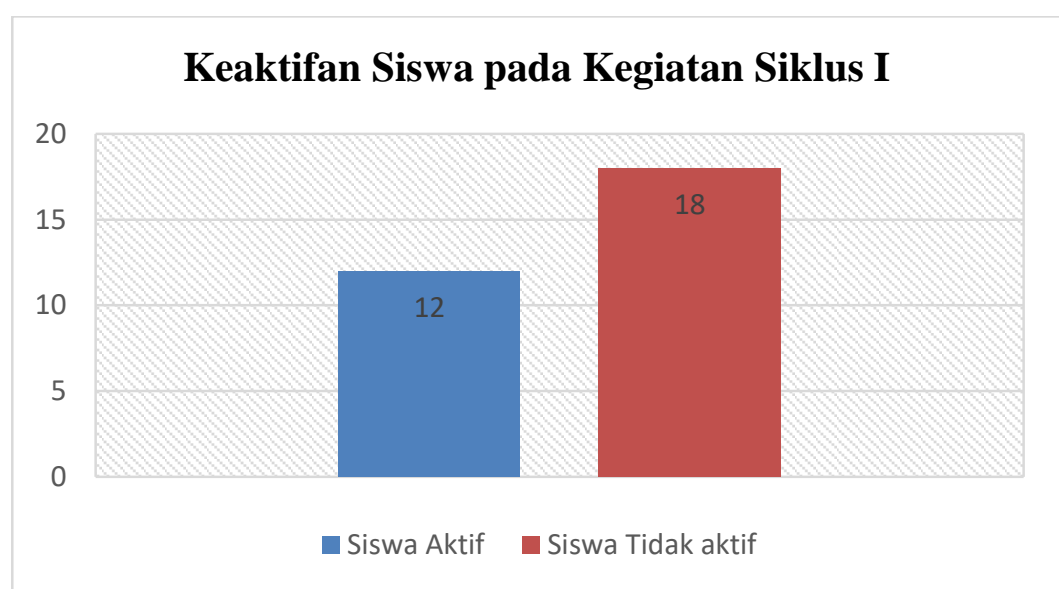

Gambar 3. Grafik Keaktifan Siswa pada Siklus 1

Tabel 4 dan Gambar 3 menunjukkan bahwa proses pembelajaran dengan menggunakan pendekatan saintifik dengan strategi pembelajaran mandiri telah memberikan dampak yang cukup signifikan. Kondisi tersebut dapat dilihat dari tingkat keaktifan siswa yang mengikuti pembelajaran mengalami peningkatan pada 
kegiatan siklus 1 ini. Terlihat sebanyak 12 siswa telah menunjukkan keaktifan dalam mengikuti mata pelajaran bahasa Indonesia. Kondisi tersebut dibuktikan dengan beberapa pertanyaan yang disampaikan oleh siswa terkait dengan materi teks prosedur. Selain itu, penyampaian materi pokok sudah mengalami kemajuan yang cukup signifikan, guru tidak lagi menyampaikan materi secara monoton dan tidak lagi menyampikan materi dengan cara ceramah. Di sisi lain, dengan persiapan yang telah dilakukan pada kegiatan plan 1, telah membuat guru menjadi lebih percaya diri dalam menyampaikan materi karena telah dipersiapkan dengan baik sebelumnya. Adapun kegiatan pembelajaran yang telah dilaksanakan pada do 1 dapat dilihat pada Gambar 4.

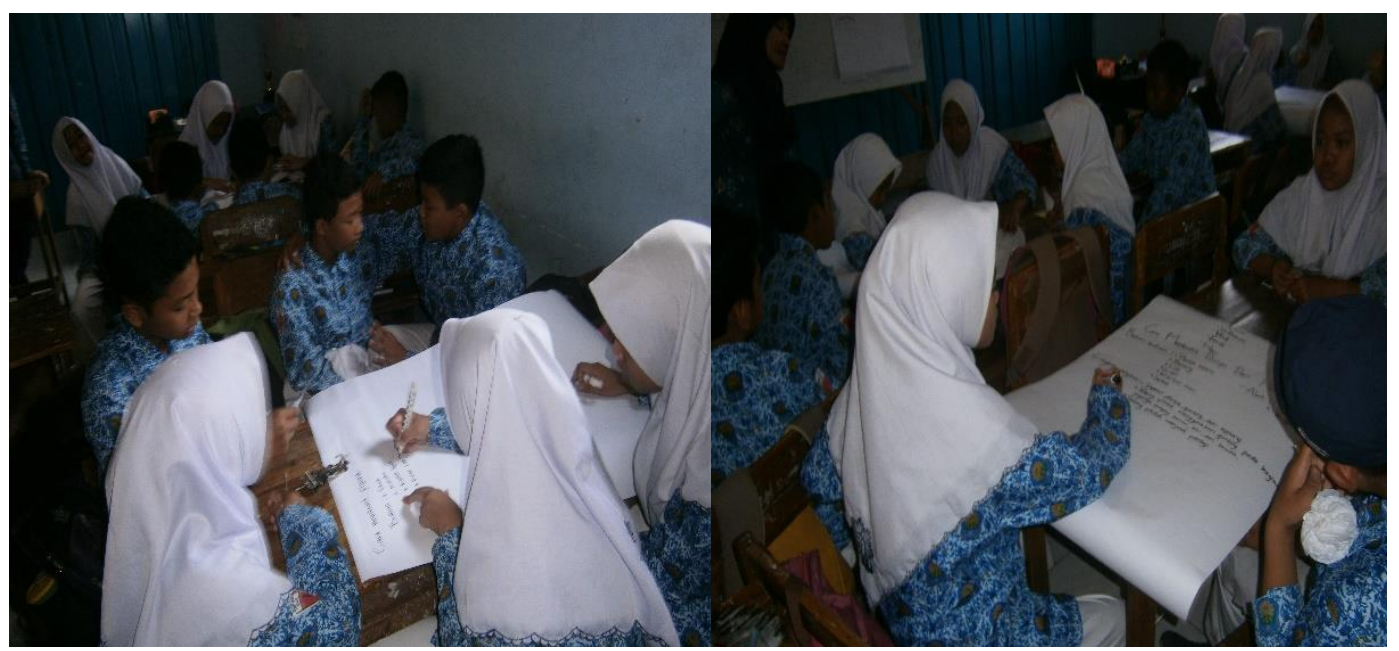

Gambar 4. Siswa Sedang Menuliskan Secara Bersama dalam Kelompok Langkah-Langkah Teks Prosedural Sederhana

See 1 adalah kegiatan evaluasi dan refleksi pelaksanaan Do 1 . See 1 bertujuan agar hasil pengamatan observer dapat langsung disampaikan, sehingga permasalahan pada Do 1 ini segera dapat ditanggapi dan segera mendapatkan solusinya. Solusi yang disimpulkan dalam kegiatan ini direkomendasikan untuk pelaksanaan Siklus II. Beberapa catatan penting yang disampaikan pada kegiatan evaluasi dan refleksi dalam See 1 adalah siswa mampu memahami konsep teks prosedural sederhana. Selain itu, siswa juga mampu memberikan contoh lain teks prosedural dalam kehidupan sehari-hari seperti cara memasak mie instan, membuat kopi, dll. Guru model mulai mampu untuk menikmati peran dan dalam menyampikan materi, sehingga proses pembelajaran lebih meningkat daripada sebelumnya. Secara umum materi sudah tersampikan dengan baik, akan tetapi guru model terlihat masih belum mampu untuk mengondiskan beberapa siswa yang duduk di belakang, sehingga proses pembelajaran sempat berjalan tidak maksimal. Berdasarkan permasalahan yang disampaikan pada kegiatan evaluasi dan refleksi dalam See 1 tersebut, tindak lanjut yang direkomendasikan sebagai upaya untuk meningkatkan keaktifan dan kemampuan berpikir kritis siswa. Adapun kegiatan pembelajaran yang telah dilaksanakan pada See 1 dapat dilihat pada Gambar 5. 


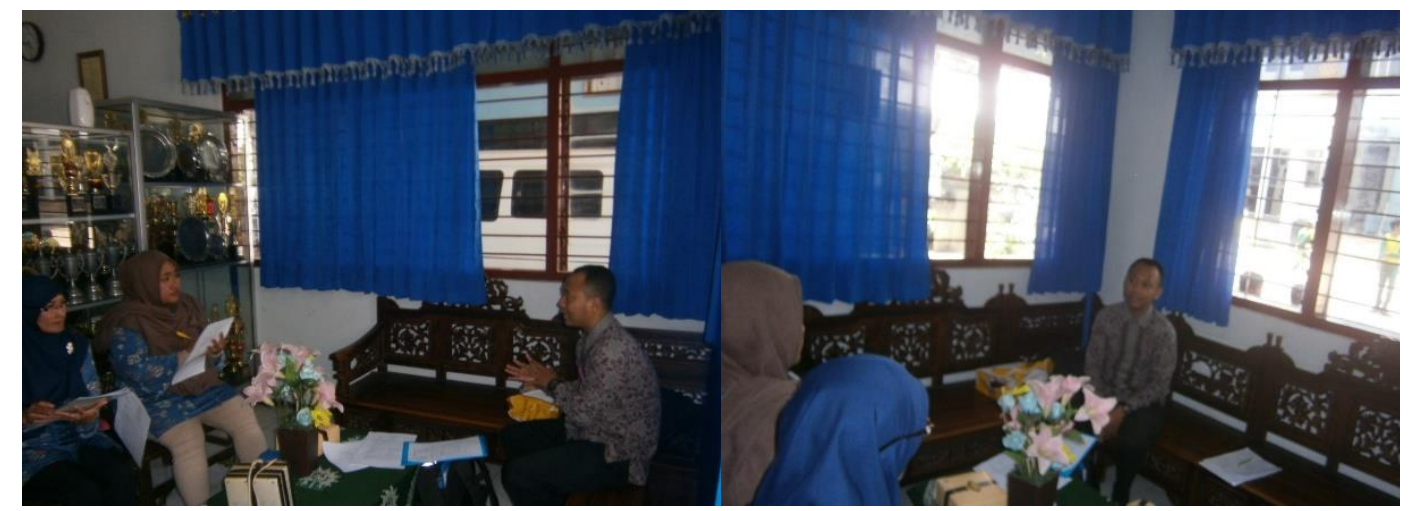

Gambar 5. Proses See (Refleksi) yang Dilakukan Setelah Proses Pembelajaran Bersama Dengan Guru Model, Guru Observer, dan Peneliti

\section{Siklus II}

Plan 2 adalah kegiatan mendiskusikan pembelajaran yang akan dilaksanakan pada $D o$ 2. Materi yang akan dilaksanakan pada $D o 2$ adalah teks prosedur dengan guru model Susiyanti, S.Pd. Pada Plan 2 ini tim mendiskusikan indikator pembelajaran. Indikator pembelajaran teks prosedural pada siklus II ini adalah teks prosedural sederhana. Untuk mencapai indikator tersebut, guru model menggunakan pendekatan saintifik dengan strategi pembelajaran mandiri yang diimplementasikan melalui metode inkuiri, pemberian tugas, dan proyek. Hasil Plan 2 adalah pemaduan antara strategi pembelajaran mandiri dengan strategi pembelajaran interaktif melalui diskusi dan sharing dalam kelompok kecil untuk mengidentifikasi teks prosedural sederhana. Untuk mendukung rancangan tersebut, maka materi pelajaran disusun untuk memotivasi siswa agar aktif bertanya dan berpikir kritis. Tindak lanjut Plan 2 adalah menyusun RPP berbasis pendekatan saintifik yang bertujuan untuk membangun inisiatif individu, peningkatan diri, dan kemampuan berpikir kritis melalui diskusi dan sharing di antara siswa. Di samping itu, menyusun materi pokok yang dapat mendorong keaktifan dan kreativitas siswa, dan lembar catatan keaktifan siswa. Kegiatan diskusi dalam plan sebagaimana pada Gambar 6.

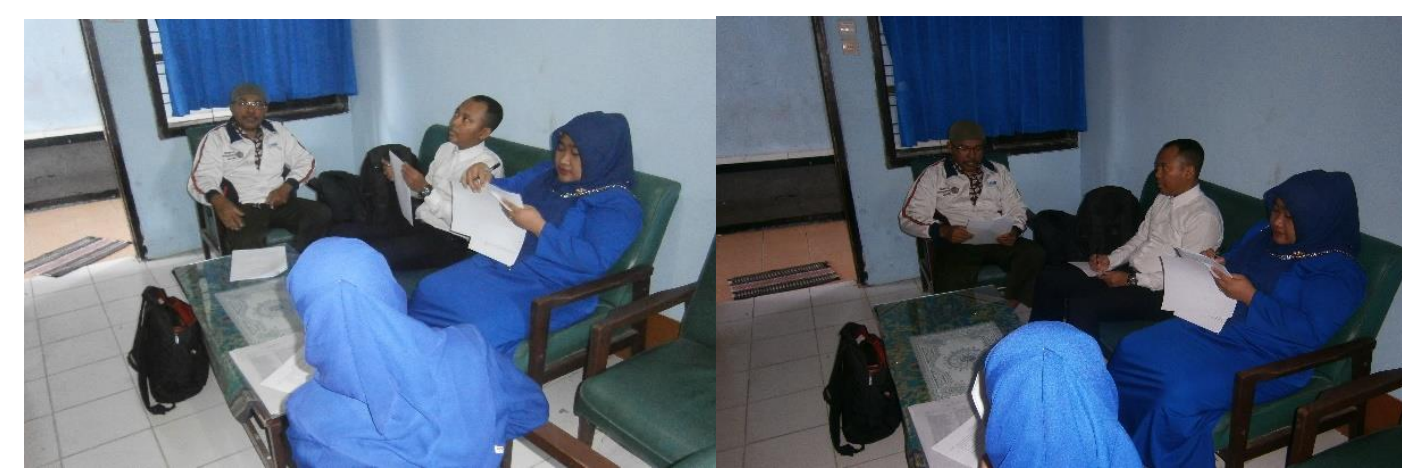

Gambar 6. Kegiatan Plan Dengan Guru Model, Guru Observer, dan Peneliti

Do 2 adalah kegiatan melaksanakan pembelajaran. Dalam kegiatan ini siswa mengidentifikasi teks prosedural sederhana. Do 2 menghadirkan beberapa aktivitas pembelajaran yang terkait dengan kegiatan mengidentifikasi teks prosedural sederhana. Aktivitas pembelajaran diawali dengan penyampaian materi pokok oleh 
guru model selama \pm 45 menit. Selama penyampaian materi pokok tersebut, guru model memberi contoh teks prosedural sederhana melalui vidio, sehingga menarik perhatian siswa dan memberikan stimuls pada sisiwa untuk aktif bertanya mengenai contoh vidio teks prosedural. Di samping itu, penyampaian materi pokok sudah sesuai dengan kegiatan plan. Stimulus yang telah diberikan oleh guru menjadi sebuah modal yang sangat bagus untuk memancing siswa lebih aktif. Pembelajaran yang dilaksanakan pada do 2 telah dirancang sebelumnya oleh guru model menggunakan pendekatan saintifik dengan strategi pembelajaran mandiri yang diimplementasikan melalui metode inkuiri, pemberian tugas, dan proyek. Model pembelajaran tersebut memberikan dampak yang cukup signifikan terhadap proses pembelajaran yang diselenggarakan, utamanya pada keaktifan siswa dan kemampuan berpikir kritis. Hal ini ditunjukkan dengan antusiasme yang cukup tinggi untuk mengikuti pembelajaran pada do 2, kondisi ini dapat dilihat pada Tabel 5 dan Gambar 7.

Tabel 5. Rubrik Keaktifan Siswa pada Kegiatan Siklus I

\begin{tabular}{|c|c|c|c|c|c|c|c|c|c|c|c|c|}
\hline \multirow[t]{2}{*}{ No } & \multirow[t]{2}{*}{ Nama Siswa } & \multicolumn{3}{|c|}{ Bertanya } & \multicolumn{3}{|c|}{ Menjawab } & \multicolumn{3}{|c|}{$\begin{array}{c}\text { Argumen/Sol } \\
\text { usi }\end{array}$} & \multirow{2}{*}{$\begin{array}{l}\text { Total } \\
\text { Skor }\end{array}$} & \multirow[t]{2}{*}{ Nilai } \\
\hline & & 1 & 2 & 3 & 1 & 3 & 5 & 5 & 7 & 8 & & \\
\hline 1 & A & $\sqrt{ }$ & - & - & $\sqrt{ }$ & - & - & $\sqrt{ }$ & - & - & 7 & 77,77 \\
\hline 2 & B & - & $\sqrt{ }$ & - & $\sqrt{ }$ & - & - & - & - & $\sqrt{ }$ & 11 & 122,22 \\
\hline 3 & $\mathrm{C}$ & - & - & $\sqrt{ }$ & - & - & $\sqrt{ }$ & - & $\sqrt{ }$ & - & 15 & 166,66 \\
\hline 4 & D & - & - & $\sqrt{ }$ & - & $\sqrt{ }$ & - & - & - & $\sqrt{ }$ & 14 & 155,55 \\
\hline 5 & E & - & - & $\sqrt{ }$ & - & - & $\sqrt{ }$ & $\sqrt{ }$ & - & - & 13 & 144,44 \\
\hline 6 & F & - & - & - & - & - & - & - & - & - & - & - \\
\hline 7 & G & - & $\sqrt{ }$ & - & - & $\sqrt{ }$ & - & - & $\sqrt{ }$ & - & 12 & 133,33 \\
\hline 8 & $\mathrm{H}$ & - & - & - & - & - & - & - & - & - & - & - \\
\hline 9 & I & - & - & $\sqrt{ }$ & - & $\sqrt{ }$ & - & - & $\sqrt{ }$ & - & 13 & 144,44 \\
\hline 10 & $\mathrm{~J}$ & - & - & - & - & - & - & - & - & - & - & - \\
\hline 11 & K & - & $\sqrt{ }$ & - & $\sqrt{ }$ & - & - & - & $\sqrt{ }$ & - & 10 & 111,11 \\
\hline 12 & $\mathrm{~L}$ & - & - & - & - & - & - & - & - & - & - & - \\
\hline 13 & M & - & $\sqrt{ }$ & - & - & $\sqrt{ }$ & - & - & - & $\sqrt{ }$ & 13 & 144,44 \\
\hline 14 & $\mathrm{~N}$ & - & - & $\sqrt{ }$ & - & $\sqrt{ }$ & - & - & $\sqrt{ }$ & - & 13 & 144,44 \\
\hline 15 & $\mathrm{O}$ & - & - & $\sqrt{ }$ & - & - & $\sqrt{ }$ & - & - & $\sqrt{ }$ & 16 & 177,77 \\
\hline 16 & $\mathrm{P}$ & - & - & - & - & - & - & - & - & - & - & - \\
\hline 17 & $\mathrm{Q}$ & - & $\sqrt{ }$ & - & - & $\sqrt{ }$ & - & - & $\sqrt{ }$ & - & 12 & 133,33 \\
\hline 18 & $\mathrm{R}$ & - & - & $\sqrt{ }$ & - & $\sqrt{ }$ & - & - & $\sqrt{ }$ & - & 13 & 144,44 \\
\hline 19 & $\mathrm{~S}$ & - & - & - & - & - & - & - & - & - & - & - \\
\hline 20 & $\mathrm{~T}$ & $\sqrt{ }$ & - & - & $\sqrt{ }$ & - & - & $\sqrt{ }$ & - & - & 7 & 77,77 \\
\hline 21 & U & - & - & - & - & - & - & - & - & - & - & - \\
\hline 22 & V & - & - & $\sqrt{ }$ & - & $\sqrt{ }$ & - & - & $\sqrt{ }$ & - & 13 & 144,44 \\
\hline 23 & W & - & - & - & - & - & - & - & - & - & - & - \\
\hline 24 & $\mathrm{Q}$ & - & $\sqrt{ }$ & - & - & $\sqrt{ }$ & - & - & $\sqrt{ }$ & - & 12 & 133,33 \\
\hline 25 & Y & - & - & - & - & - & - & - & - & - & - & - \\
\hline 26 & Z & - & $\sqrt{ }$ & - & $\sqrt{ }$ & - & - & $\sqrt{ }$ & - & - & 8 & 88,88 \\
\hline 27 & AA & - & - & - & - & - & - & - & - & - & - & - \\
\hline 28 & $\mathrm{AB}$ & $\sqrt{ }$ & - & - & $\sqrt{ }$ & - & - & - & $\sqrt{ }$ & - & 9 & 100 \\
\hline 29 & $\mathrm{AC}$ & - & $\sqrt{ }$ & - & - & $\sqrt{ }$ & - & - & $\sqrt{ }$ & - & 12 & 133,33 \\
\hline 30 & $\mathrm{AD}$ & - & $\sqrt{ }$ & - & - & $\sqrt{ }$ & - & $\sqrt{ }$ & - & - & 10 & 111,11 \\
\hline
\end{tabular}




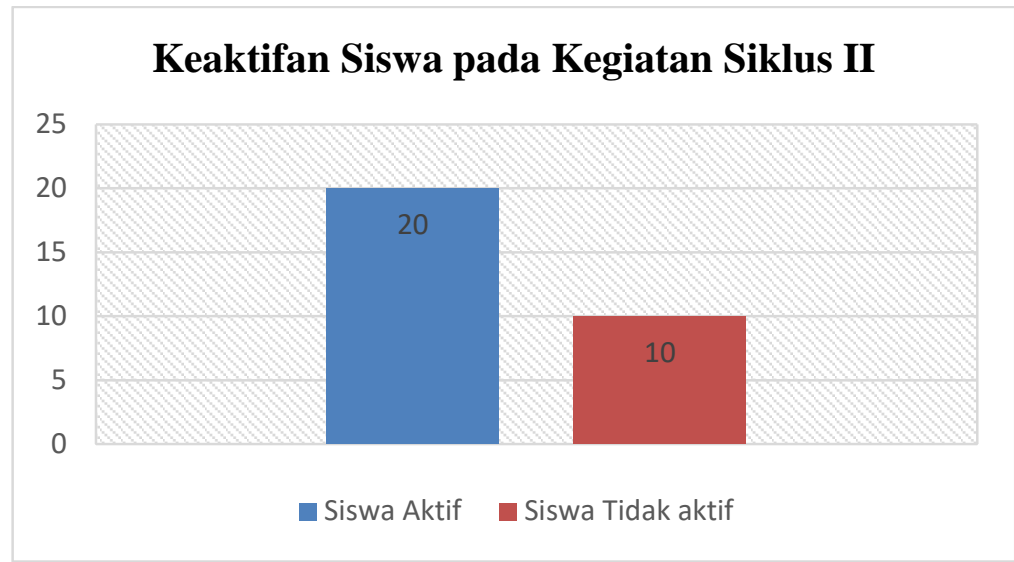

Gambar 7. Grafik Keaktifan Siswa pada Siklus 2

Tabel 5 dan Gambar 7 menunjukkan bahwa proses pembelajaran dengan menggunakan pendekatan saintifik dengan strategi pembelajaran mandiri telah memberikan dampak yang cukup signifikan. Kondisi tersebut dapat dilihat dari tingkat keaktifan siswa yang mengikuti pembelajaran mengalami peningkatan pada kegiatan siklus 2 ini. Terlihat sebanyak 20 siswa telah menunjukkan keaktifan dalam mengikuti mata pelajaran bahasa Indonesia. Kondisi tersebut dibuktikan dengan pertanyaan yang cukup banyak disampaikan oleh siswa terkait dengan materi teks prosedur. Selain itu, penyampaian materi pokok sudah mengalami kemajuan yang cukup signifikan, guru tidak lagi menyampaikan materi secara monoton dan tidak lagi menyampikan materi dengan cara ceramah, melainkan dengan menggunakan vidio. Di sisi lain, dengan persiapan yang telah dilakukan pada kegiatan plan 2, telah membuat guru menjadi lebih percaya diri dalam menyampaikan materi karena telah dipersiapkan dengan baik sebelumnya. Selain itu, guru sudah mulai menikmati dalam menyampaikan materi dan melibatkan siswa dalam proses pembelajaran. Adapun kegiatan pembelajaran yang telah dilaksanakan pada do 2 dapat dilihat pada Gambar 8.

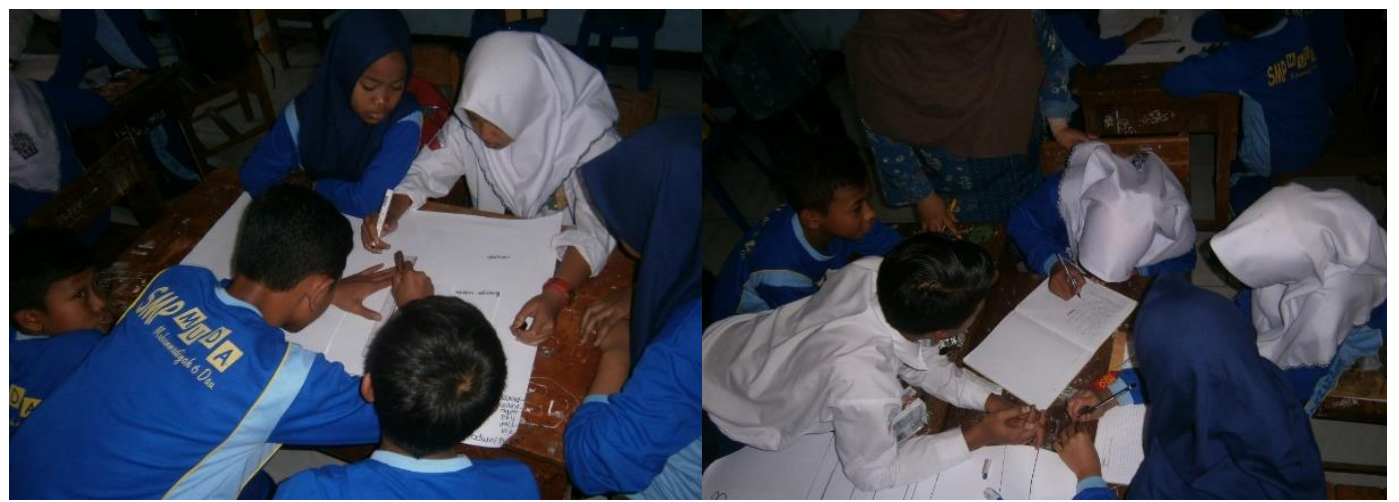

Gambar 8. Siswa sedang Menuliskan Secara Bersama dalam Kelompok Langkah-Langkah Teks Prosedural Sederhana

See 2 adalah kegiatan evaluasi dan refleksi pelaksanaan Do 2. See 2 bertujuan agar hasil pengamatan observer dapat langsung disampaikan, sehingga permasalahan pada Do 2 ini segera dapat ditanggapi dan segera mendapatkan solusinya. Solusi yang disimpulkan dalam kegiatan ini direkomendasikan untuk perbaikan pembelajaran ke depannya. Beberapa permasalahan dan sisi positif 
pembelajaran Do 2 yang disampaikan pada kegiatan evaluasi dan refleksi dalam See 2 adalah siswa mampu memahami konsep teks prosedural sederhana. Selain itu, siswa juga mampu memberikan contoh lain teks prosedural sederhana dalam kehidupan sehari-hari seperti cara membuat tahu, membuat bakso, dll. Guru model mulai mampu untuk menyampaikan materi dan megiring pemahaman siswa untuk memahami konsep dasar teks prosedural, sehingga proses pembelajaran lebih meningkat daripada siklus sebelumnya. Secara umum materi sudah tersampikan dengan baik, akan tetapi guru model di awal pembelajaran terlihat masih sedikit gugup dan ragu dengan materi yang akan disampikan. Berdasarkan permasalahan yang disampaikan pada kegiatan evaluasi dan refleksi dalam See 2 tersebut, tindak lanjut yang direkomendasikan sebagai upaya untuk meningkatkan keaktifan siswa dalam pembelajaran dan kemampuan berpikir kritis siswa. Adapun kegiatan pembelajaran yang telah dilaksanakan pada See 2 dapat dilihat pada Gambar 9.

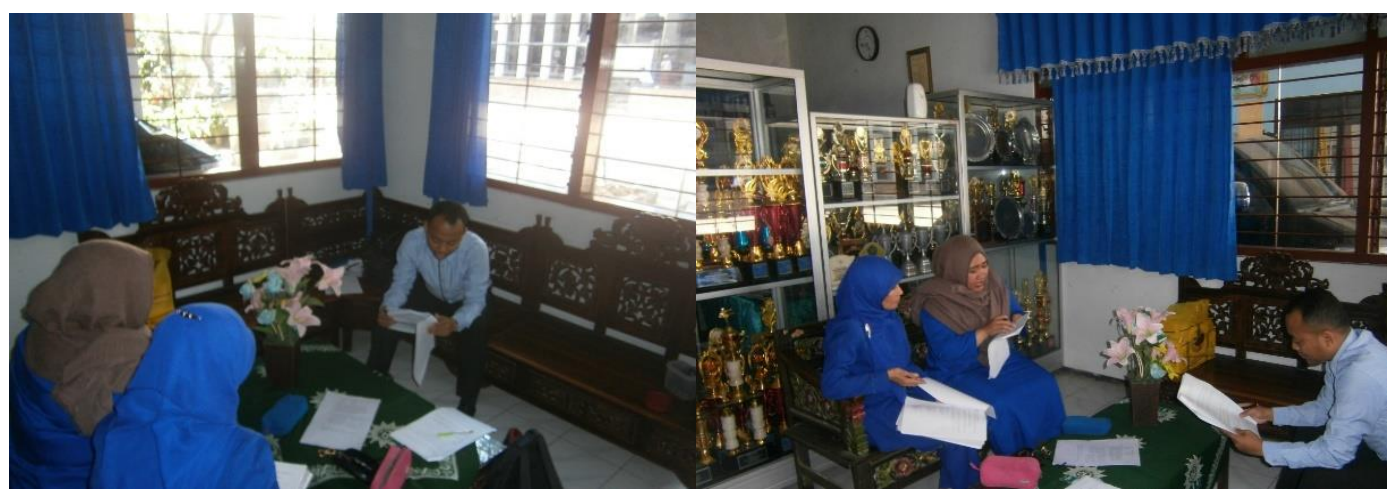

Gambar 9. Proses See (Refleksi) yang Dilakukan Setelah Proses Pembelajaran Bersama dengan Guru Model, Guru Observer, dan Peneliti

\section{Pembahasan}

Berdasarkan Tabel 4 serta 5 dan Gambar 3 serta 5 menunjukkan bahwa keaktifan siswa mengalami peningkatan pada setia siklusnya. Berkaitan dengan kondisi tersebut penggunaan pendekatan saintifik dalam pembelajaran mampu meningkatkan keaktifan dan kemampuan berpikir kritis siswa (Machin, 2014; Setiawan, 2019; Sukmasari et al., 2015; Wijayanti, 2014). Selain itu, penyelenggaraan kegiatan lesson study dalam pelajaran bahasa Indonesia sangat membantu guru dan juga siswa dalam melaksanakan pembelajaran (Tristiantari \& Sumantri, 2016), sehingga banyak memberikan pengalaman baru bagi guru dan siswa (Wulandari et al., 2015). Pendekatan saintifik dan lesson study merupakan model yang dapat digunakan untuk menyelenggarakan pembelajaran menjadi menarik dan komunikatif (Dewi, 2016; Jurniati, 2009; Rustono, 2008; Wijayanti, 2014).

Berdasarkan kegiatan pembelajaran yang telah diselenggarakan pada siklus I dan siklus II pada penelitian ini, ternyata mampu meningkatkan keaktifan siswa. Melalui kegiatan pembelajaran yang menggunakan lesson study memberikan banyak pengalaman belajar yang baru kepada siswa, sehingga mendorong siswa untuk lebih aktif dalam pembelajaran (Susanto, 2012; Yulianto et al., 2017). Hal ini sejalan dengan pendapat Murtiani et al. (2012), Pantiwati (2015), dan Agustiana et al. (2018) yang menyatakan bahwa pembelajaran yang menggunakan lesson study lebih banyak memberikan ruang pada siswa untuk melakukan eksplorasi terhadap pembelajaran, sehingga menjadikan siswa aktif dan tanggap dalam pembelajaran. 
Adapun peningkatan keaktifan siswa dalam proses pembelajaran dapat dilihat pada Gambar 10. Secara umum, pembelajaran bahasa Indonesia yang diselenggarakan di SMP Muhammadiyah 6 Dau menggunakan pendekatan saintifik dan lesson study telah mampu meningkatkan keaktifan siswa. Hal ini menjadi sebuah temuan baru dalam penelitian ini, karena selama ini pendekatan saintifik dan lesson study masih sangat dominan digunakan pada mata pelajaran IPA. Dengan demikian, hasil penelitian ini menunjukkan bahwa pendekatan saintifik dan lesson study dapat digunakan pada semua mata pelajaran di sekolah.

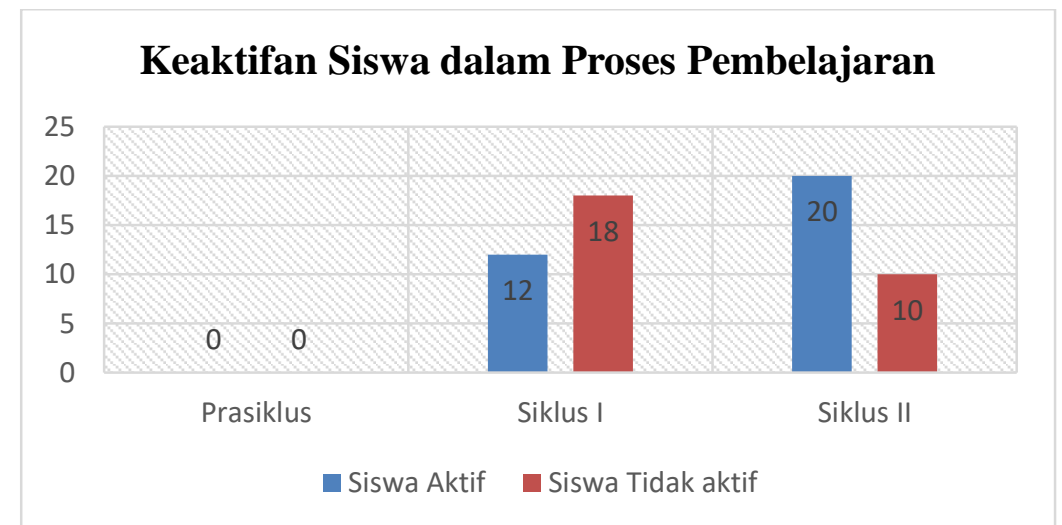

Gambar 7. Grafik Keaktifan Siswa pada Prasiklus, Siklus I, dan Siklus 2

\section{SIMPULAN}

Keaktifan siswa kelas VII SMP Muhammadiyah 6 Dau dapat ditingkatkan melalui implementasi pembelajaran dengan pendekatan saintifik dalam kegiatan lesson study pada mata pelajaran bahasa Indonesia. Peningkatan terlihat dari hasil pengamatan berbagai aktivitas belajar mahasiswa dalam proses pembelajaran yang meliputi: (1) menanya, (2) menjawab, dan (3) mengomunikasikan/menanggapi teks prosedur. Peningkatan tersebut pada dasarnya mengiringi proses pembelajaran yang semakin dinamis melalui praktik baik (best practice) pembelajaran yang memadukan beberapa strategi dan metode pembelajaran. Hal ini ditunjukkan dengan semakin meningkatnya jumlah siswa yang aktif pada masing-masing siklus. Siklus I menunjukkan sebanyak 12 siswa yang aktif, dan siklus II menunjukkan sebanyak 20 siswa yang aktif dalam proses pembelajaran. Kondisi tersebut menunjukkan bahwa program lesson study ini dapat meningkatkan iklim belajar menjadi semakin kondusif melalui kesiapan guru dan siswa. Penelitian ini dapat memberikan informasi mengenai kelebihan pendekatan saintifik dalam kegiatan lesson study dalam proses pembelajaran. Selain itu, penelitian lain yang mengaji tentang pendekatan saintifik dalam kegiatan lesson study pada mata pelajaran bahasa Indonesia perlu secara konsisten dilakukan. Hal ini agar lebih banyak infromasi yang didapatkan mengenai pendekatan saintifik dalam kegiatan lesson study pada mata pelajaran non-IPA.

\section{DAFTAR PUSTAKA}

Agustiana, E., Putra, F. G., \& Farida, F. (2018). Penerapan model pembelajaran Auditory, Intellectually, Repetition (AIR) dengan pendekatan lesson study terhadap kemampuan pemecahan masalah matematis peserta didik. Desimal: Jurnal Matematika, 1(1), 1-6. 
Bintari, N. L. G. R. P., Sudiana, I. N., \& Putrayasa, I. B. (2014). Pembelajaran Bahasa Indonesia Berdasarkan Pendekatan Saintifik (Problem Based Learning) Sesuai Kurikulum 2013 di Kelas VII SMP Negeri 2 Amlapura. Jurnal Pendidikan dan Pembelajaran Bahasa Indonesia, 3(1).

Dewi, P. S. (2016). Kemampuan proses sains siswa melalui pendekatan saintifik dalam pembelajaran ipa terpadu pada tema global warming. EDUSAINS, 8(1), 18-26.

Gidot, S., Mashudi, H., \& Matsum, J. H. (2013). Pengaruh kompetensi profesional guru dan minat belajar terhadap hasil belajar akuntansi siswa kelas XI. Jurnal Pendidikan dan Pembelajaran Khatulistiwa, 3(3), 1-14.

Hardini, T. (2015). Peningkatan keaktifan dan hasil belajar siswa dalam pembelajaran PKn melalui metode sosiodrama di kelas 5 SD Tlompakan 01-Tuntang. Scholaria: Jurnal Pendidikan Dan Kebudayaan, 5(3), 120135.

Jurniati, J. (2009). Penerapan model pembelajaran lesson study praktikum wisata untuk meningkatkan penguasaan konsep dan berpikir kreatif siswa kelas X SMA N 1 Langgam Pelalawan. Jurnal Geliga Sains: Jurnal Pendidikan Fisika, 3(1), 1-9.

Kristanto, T., Hapsari, R. K., Nita, V. S., \& Maimunah, S. (2015). Rancang Bangun Aplikasi E-Learning Berbasis Multiplatform untuk Mata Pelajaran Bahasa Indonesia dengan Menggunakan Pendekatan Technology Acceptance Model (TAM). Jurnal Teknik Informatika dan Sistem Informasi, 1(3).

Kristina, M. (2018). Implementasi model pembelajaran direct learning pada mata pelajaran bahasa Indonesia materi menulis cerita guna meningkatkan minat belajar siswa kelas II SDN 3 Karangraja. INVENTA: Jurnal Pendidikan Guru Sekolah Dasar, 2(2), 46-54.

Machin, A. (2014). Implementasi pendekatan saintifik, penanaman karakter dan konservasi pada pembelajaran materi pertumbuhan. Jurnal Pendidikan IPA Indonesia, 3(1), 28-35.

Mardiyan, R. (2012). Peningkatkan keaktifan dan hasil belajar siswa dalam pembelajaran akuntansi materi jurnal penyesuaian pada siswa kelas xi ips 3 SMA Negeri 3 Bukittinggi dengan metode bermain peran (role playing). Pakar Pendidikan, 10(2), 151-162.

Megawati, Y. D. N., \& Sari, A. R. (2012). Model pembelajaran kooperatif tipe team assisted individualization (TAI) dalam meningkatkan keaktifan siswa dan hasil belajar akuntansi siswa kelas XI IPS 1 SMA Negeri 1 Banjarnegara Tahun Ajaran 2011/2012. Jurnal Pendidikan Akuntansi Indonesia, 10(1), 162-180.

Murtiani, M., Fauzan, A., \& Ratnawulan, R. (2012). Penerapan pendekatan contextual teaching and learning (CTL) berbasis lesson study dalam meningkatkan kualitas pembelajaran fisika di SMP NEGERI kota Padang. Jurnal Penelitian Pembelajaran Fisika, 1(1), 1-21.

Mustofa, Z., Susilo, H., \& Al Muhdhar, M. H. I. (2016). Penerapan model pembelajaran problem based learning melalui pendekatan kontekstual berbasis lesson study untuk meningkatkan kemampuan memecahkan masalah dan hasil belajar kognitif siswa SMA. Jurnal Pendidikan: Teori, Penelitian, dan Pengembangan, 1(5), 885-889. 
Nurhayati, E. (2020). Meningkatkan keaktifan siswa dalam pembelajaran daring melalui media game edukasi quiziz pada masa pencegahan penyebaran covid-19. Jurnal Paedagogy, 7(3), 145-150.

Pantiwati, Y. (2015). Pemanfaatan Lingkungan Sekolah sebagai Sumber Belajar dalam Lesson Study untuk Meningkatkan Metakognitif. Jurnal Bioedukatika, 3(1), 27-32.

Permatasari, E. A. (2014). Implementasi pendekatan saintifik dalam kurikulum 2013 pada pembelajaran sejarah. Indonesian Journal of History Education, 3(1), 11-16.

Rahayu, P., Mulyani, S., \& Miswadi, S. (2012). Pengembangan pembelajaran IPA terpadu dengan menggunakan model pembelajaran problem base melalui lesson study. Jurnal Pendidikan IPA Indonesia, 1(1), 63-70.

Ramlah, R., Firmansyah, D., \& Zubair, H. (2015). Pengaruh Gaya Belajar dan Keaktifan Siswa terhadap Prestasi Belajar Matematika (Survey Pada SMP Negeri di Kecamatan Klari Kabupaten Karawang). Majalah Ilmiah SOLUSI, 1(3), 68-75.

Rudyanto, H. E. (2016). Model discovery learning dengan pendekatan saintifik bermuatan karakter untuk meningkatkan kemampuan berpikir kreatif. Premiere Educandum: Jurnal Pendidikan Dasar dan Pembelajaran, 4(1), 41-48.

Rusminati, S. H., \& Sulistyawati, I. (2018). Implementasi lesson study menggunakan model think pair share dan pendekatan saintifik. Premiere Educandum: Jurnal Pendidikan Dasar dan Pembelajaran, 8(1), 88-97.

Rustono, W. (2008). Meningkatkan kemampuan mahasiswa menerapkan strategi pembelajaran melalui lesson study di sekolah dasar. Jurnal pendidikan dasar, 10, 1-7.

Setiawan, A. R. (2019). Efektivitas pembelajaran biologi berorientasi literasi saintifik. Thabiea: Journal of Natural Science Teaching, 2(2), 83-94.

Setiawan, A. R. (2020). Peningkatan literasi saintifik melalui pembelajaran biologi menggunakan pendekatan saintifik. Journal of Biology Education, 2(1), 113.

Setiawan, A. R., \& Mufassaroh, A. Z. (2020). Lembar kegiatan siswa untuk pembelajaran jarak jauh berdasarkan literasi saintifik pada topik penyakit coronavirus 2019 (COVID-19).

Sukmasari, N. N., Putra, I. K. A., \& Kristiantari, M. R. (2015). Pengaruh pendekatan saintifik berbasis asesmen portofolio terhadap hasil belajar keterampilan menulis dan kemampuan berpikir kritis siswa kelas IV SD gugus pattimura pada Ttema cita-citaku. MIMBAR PGSD Undiksha, 3(1).

Sundari, N. (2013). Penggunaan Media Gambar dalam Meningkatkan Keaktifan Siswa dalam Pembelajaran Pengetahuan Sosial di Sekolah Dasar. EduHumaniora| Jurnal Pendidikan Dasar Kampus Cibiru, 5(1), 1-7.

Susanto, J. (2012). Pengembangan perangkat pembelajaran berbasis lesson study dengan kooperatif tipe numbered heads together untuk meningkatkan aktivitas dan hasil belajar IPA di SD. Journal of Primary Education, 1(2), 71-77.

Tristiantari, N. K. D., \& Sumantri, I. M. (2016). Model pembelajaran cooperatif integrated reading composition berpola lesson study meningkatkan keterampilan membaca dan menulis. JPI (Jurnal Pendidikan Indonesia), 5(2), 203-211. 
Wardiati, Z. (2017). Penerapan metode SASMG (struktural analitik sintetik dan matode global) untuk meningkatkan motivasi dan hasil belajar peserta didik pada mata pelajaran bahasa Indonesia kelas I di SDN 3 Kopang Kec. Kopang tahun pelajaran 2015/2016. Jurnal Ilmiah Mandala Education, $3(2), 51-56$.

Wibowo, N. (2016). Upaya peningkatan keaktifan siswa melalui pembelajaran berdasarkan gaya belajar di SMK Negeri 1 Saptosari. Elinvo (Electronics, Informatics, and Vocational Education), 1(2), 128-139.

Widhiyasari, M., Umami, N., \& Suja, I. S. (2019). Pengaruh penggunaan media sosial whatsapp terhadap keaktifan siswa pada mata pelajaran ekonomi bisnis kelas X SMK Negeri 2 Boyolangu tahun ajaran 2018/2019. Jurnal Pendidikan Ekonomi, 12(2), 94-98. Retrived from: http://journal2.um.ac.id/index.php/jpe/article/view/8983/4536

Wijayanti, A. (2014). Pengembangan autentic assesment berbasis proyek dengan pendekatan saintifik untuk meningkatkan keterampilan berpikir ilmiah mahasiswa. Jurnal Pendidikan IPA Indonesia, 3(2).

Winarsih, \& Sulistyowati, R. (2016). Penerapan pendekatan saintifik dalam Mata Kuliah Umum (MKU) Bahasa Indonesia untuk menumbuhkan budaya menulis mahasiswa IKIP PGRI Madiun. Widyabastra: Jurnal Ilmiah Pembelajaran Bahasa dan Sastra Indonesia, 4(2), 141-157.

Winarsih, A., \& Mulyani, S. (2012). Peningkatan profesionalisme guru IPA melalui lesson study dalam pengembangan model pembelajaran PBI. Jurnal Pendidikan IPA Indonesia, 1(1), 43-50.

Wulandari, B., Arifin, F., \& Irmawati, D. (2015). Peningkatan kemampuan kerjasama dalam tim melalui pembelajaran berbasis lesson study. Elinvo (Electronics, Informatics, and Vocational Education), 1(1), 9-16.

Yulianto, A., Fatchan, A., \& Astina, I. K. (2017). Penerapan model pembelajaran project based learning berbasis lesson study untuk meningkatkan keaktifan belajar siswa. Jurnal Pendidikan: Teori, Penelitian, dan Pengembangan, 2(3), 448-453. 